\title{
Islamism and nationalism among niqabis women in Egypt and Indonesia
}

\author{
Siti Ruhaini Dzuhayatin \\ Universitas Islam Negeri Sunan Kalijaga Yogyakarta \\ E-mail: siti.dzuhayatin@uin-suka.ac.id \\ DOI: 10.18326/ijims.v10i1.49-77
}

\begin{abstract}
The phenomenon of the increasing number of niqabis in Indonesia and Egypt has become concern to the government, academics and also civil society. This is due to the involvement of the niqabis or women with the niqab in terrorist networks. The piece of clothing covering the face is not merely a manifestation of faith but it apparently entails a certain ideological doctrine of the so-called Islam kaffah (ultimate Islam) through the establishemnt of Islamic khilafah (Islamic caliphate) as opposed to democracy and modern state. This study aims at observing the extent to which the niqabis negotiate Islam and their nationalism in their respective countries in Indonesia and Egypt where Muslims constitute the majority of the population. This study employed a mix of methods, qualitative and quantitative, involving 205 Niqabis from Indonesia and 87 niqabis from Egypt. The quantitative data were obtained from 292 respondents, while the qualitiative data were collected from 27 niqabis using in-depth interviews through life story technique-6 Egyptians and 21 Indonesians. A number of 12 prominent figures in Egypt and Indonesia were interviewed and two focus group discussions were conducted in both countries involving women activists, academics, government employees, and religious leaders. The framework of this study is the contestation
\end{abstract}


between Islamism and nationalism. This study indicated that there is a significant difference between the niqabis of Indonesia and Egypt in terms of their perception of national pride. Around 30 percent of Indonesian niqabis are not proud of being Indonesian citizens while in Egypt only about 3 percent. Bank interest is used to measure their Islamic refinement through which Niqabis in both countries share a similar view, where almost $90 \%$ of them believe that the practice is not Islamic. Moreover, more than 50\% support the Caliphate system, which means that one in four niqabis considers that the existing government is thoghut (non Islamic) and nearly $15 \%$ agree to defend Islam by means of violence.

Fenomena berkembangnya niqabis di Indonesia dan Mesir menjadi perhatian seksama pemerintah, akademisi dan juga masyarakat sipil. Hal ini disebabkan keterlibatan perempuan dalam jaringan teroris yang umumnya menggunakan niqab, sehingga diduga bahwa selembar kain penutup wajah ini tidak semata simbul ketaqwaan tetapi ada bagian dari doktrin ideologi yang melawan sistem yang ada. Pada umumnya, ideologi ini bermaksud mendirikan sistem caliphate yang dilawankan dengan demokrasi dan bentuk negara republik. Penelitian ini bertujuan untuk mengetahui sejauhmana tingkat Islamisme dan nasionalisme para niqabis di Indonesia dan Mesir, sebagai negara dengan mayoritas Muslim. Penelitian ini menggunakan mix-methode, kualitatif dan kuantitatif yang melibatkan 205 Niqabis dari Indonesia dan 87 niqabis dari Mesir. Data kuantitatif diperoleh dari 209 responden melalui kuesioner sedangkan data kualitatif diperoleh melalui wawancara mendalam dengan teknis kisah hidup sebanyak 27, 6 Niqabis Mesir dan 21 Niqabis Indonesia. Disamping itu, dilakukan wawancara dengan 12 tokoh dan dilaksanakan dua diskusi terfokus dengan politisi, aktivis perempuan, akademisi, pegawai pemerintah, dan pemimpin agama. Penelitian ini menggunakan kerangka kerja kontestasi Islamisme dan nasionalisme yang menunjukan hasil sebagai berikut: ada perbedaan signifikan antara niqabis kedua negara pada aspek kebanggaan sebagai warga negara. Hampir 30 persen niqabis Indonesia tidak bangga menjadi WNI sedangkan di Mesir hanya sekitar 3 persen. Jasa Bank digunakan untuk mengukur kehidupan Islami yang menunjukkan kecenderungan sama, meski dengan prosentase yang sedikit berbeda, yaitu lebih dari $90 \%$ tidak setuju dengan bunga bank. Terkait dengan politik, lebih dari 
$50 \%$ setuju dengan sistem caliphate dan 1 dari 4 niqabis setuju bahwa pemerintah saat ini thoghut dan sekitar 15 orang setuju menggunakan kekerasan dalam membela negara.

Keywords: Niqabis; Islamism; Nationalism; Caliphate

\section{Introduction}

Women issues, ranging from their identities, roles, positions and even personal choices, continue being contested so long as their voices are not heard and their autonomy is not recognized. According to Kumari Jayawardena, Feminists remain critical on how women are postulated in socio-cultural, economics, politics as well as religion in the major patriarchal narrative. ${ }^{1}$ Women are constantly in a dilemma on how to control their own bodies, including the choice of dressing or covering their bodies. Feminist theories started questioning control over body as the fundamental ground for claiming their personal authorities as strongly advocated by Kate Millett in seeing body and sex as part of power relationships and personal contacts on th recognized political structruces. ${ }^{2}$ Conal Hanisch, known as the initiator of the very famous campaign on 'the personal is political,' claims that women authority, including appreance, is recognized as personal autonomy. ${ }^{3}$ Fatima Mernissi asserted that the veil in the Muslim world is often used in misogynistic patriarchal tradition to curb women's right and participation in the modern and democratic world. ${ }^{4}$ It is interesting to observe where women's outfits such as veil,

\footnotetext{
${ }^{1}$ Kumari Jayawardena, Feminism and Nationalism in The Third World: In The 19th and Early 20th Centuries, The Hague, Netherlands: Institute of Social Studies, 1982.

${ }^{2}$ Kate Millett, Sexual Politics, Urbana: University of Illinois Press, 1970, 24-25.

${ }^{3}$ Carol Hanich, The Personal is Political, www.carolhanisch.org downloaded 22 february 2019. See also Frances Rogan and Shelley Budgeon, "The Personal is Political: Assessing Feminist Fundamentals in the Digital Age”, Journal of Social Science, vol. 7, no. 132 (2008), 2-3.

${ }^{4}$ Fatima Mernissi, The Veil and The Male Elite; A Feminist Interpretation of Women's Rights in, Islam, New York: Persues Book Publications, 1992, 7-8.
} 
niqab, and others fit into the views of personal autonomy of Millett and Hanisch and the patriachal control over women's body.

Moreover, the question on women's outfit emerged along with women emancipation following the democratization process in the Muslim world. Access to education, changing roles, and even the shift to modern clothing as part of emancipation were approved as long as it supports the grand patriarchal narrative with all its arguments to control women. For example, the emancipation of women in the non-Western world should be different from that of the West because of the nobility and glory that is held in high esteem. ${ }^{5}$ Jayawardena's thesis is also reflected in the views of female emancipation figures in Indonesia, such as Kartini, or in Egypt-Huda Sha'arawi. Jayawardena's thesis is still relevant to women's issues today when patriarchy is embedded in cultural hegemony, state power, global economy as well as religious authority.

In general, post-colonial Muslim societies are generally accepting a modern concept and finding religious grounds in the Islamic traditions, including the concept of nation-state and democracy that is friendly to Islam, legal system as well as modern outfits which are nicely combined with the Islamic element of hijab, even with the enduing debates and contestations ${ }^{6}$. The image of the niqab worsened when the media labeled veiled women as terrorist wives or terrorist members. In countries where Muslims are a minority, the niqab is seen not only as a black cloth covering the heads and faces of women, but also religious, social, and political fanaticism. European countries such as Austria, Belgium, Bulgaria, Denmark, France, and the Netherlands have officially banned the use of niqab in public places because it is considered to express certain religious symbols and socio-political status. In other secular countries, even though

\footnotetext{
${ }^{5}$ Kumari Jayawardena, Feminism and Nationalism..., 12-15.

${ }^{6}$ Abdullahi Ahmed an Naim, Negotiating the Future of Sharia, Islam and the Secular State, Maasachussetts: Harvard University Press, 2008, 267-72.
} 
the niqab is not banned, the phenomenon of veiled Muslim women is always exposed to prejudice. ${ }^{?}$

This study aimed at comparing the two countries where Muslims are the majority: Indonesia and Egypt while posing a question on how women's voice and choice are contested and negotiated by patriarchy, religion, and nationalism with specific variables of the Islamic character and the nation state in multi-cultural contexts of Egypt and Indonesia. The choice of women as the focus of this study has to do with the issue of women's outfit, a very central aspect of the Islamic tradition that has a huge influence in other social dimensions, such as segregation, power relations, access, participation, and attainment of the benefits of development and progress.

It focuses on the meaning attached to a certain cloth closely identified with religious teaching and state ideology, especially in the post-colonial era. The contesting relations between West and East (read Islam) leads to a variety of patterns arranging from an antagonistic view of the incompatibility between Western modernization and Islamic tradition. This selective-constructive relationship harmoniously brings up a rational element of the two traditions that inspire a modern Muslim political system and a view about the total compatibility between the rational elements of Islam and the West.

Islamophobia and the incessant publications related to terrorism that hides behind the mask of Islam may have contributed to the emergence of 'fear' for attributes that are too prominent in the Islamic side. The Niqab is seen as displaying a fundamentalist attitude-as narrow fanaticism in the midst of diversity. Lintang Ratri said that veiled women experience twofold discrimination-marginalized as women and veil wearers, who are more marginalized ${ }^{8}$. Discourse about the niqab as a cloth covering aurat

\footnotetext{
${ }^{7}$ Lexandra Gouveia, 10 Countries Where Women Are Forbidden To Wear The Veil (Juli 2017), https://emirateswoman.com/10-countries-women-forbidden-wear-veil/.

${ }^{8}$ Lintang Ratri, "Cadar, Media, dan Identitas Perempuan Muslim”, Jurnal FORUM
} 
on the one hand with religious symbols is often marked by a negative image and, on the other hand, makes the study of the niqab something very important. The notion that the niqab is an expression of clothing representing the radical thinking of its owner needs to be revisited and further investigated. Examining the internal side of niqab women related to their views on Islam, their opinions on radicalism issues, as well as how they define themselves as niqab Muslims and citizens will certainly help uncover the stereotypical forms that often surround veiled women. This paper explores the internal views of women using the niqab or niqabis and places it in the socio-political spectrum where they live.

\section{Islamism as a religious ideology}

There are four types of Muslims, from violence-prone extremist jihadist core to more peaceful Muslims: Jihadist Muslims, Islamist Muslims, Conservative Muslims, and Pluralist Muslims. ${ }^{9}$ Jihadist Muslims: They want to impose their interpretation of Islam on all others by threat or use of force in order to achieve the others' submission and conversion. They are also the most militant and are mainly interested in fighting the 'near enemy.' Islamist Muslims: They may not practice violence but often adhere to the same, or a similar, fundamentalist and exclusivist ideology as the jihadist terrorists. In principle, they are opposed to pluralism, but for practical and pragmatic reasons, they opt for coexistence with other political parties. Conservative Muslims: They tend not to view Islam as a political ideology and are not revolutionary. They can be referred to as traditional Muslims. Pluralist Muslims: They adhere to a broader interpretation of what it means to be Islamic and are inclusivists rather than exclusivists regarding various expressions of their faith and its relationship

\footnotetext{
Universitas Diponegoro, Volume 39, Number 2 (2011), 29-37.

${ }^{9}$ Alex P. Schmid, "Moderate Muslims and Islamist Terrorism: Between Denial and Resistance", The Hague, vol. 8, No. 9 (2017).
} 
with other faiths. They include 'modern Muslims,' 'cultural Muslims,' 'sociological Muslims,' 'liberal Muslims,' 'reformist Muslims,' 'progressive Muslims,' 'Western Muslims,' 'Muslim democrats,' and the 'Muslim left.'

Based upon the aforementioned classification, the first to the third group tend to close to Islamism. The word Islamism has various definitions. But, in general, the term Islamism appears as a substitute for the term fundamentalism and the term political Islam, which tends to be stigmatic ${ }^{10}$. Islamism is a visionary movement set to shape world records based upon religion and allows violence, which has six spectrums namely: 1) Purification of Islam, 2) Formalization of Islamic Sharia, 3) Anti-Democracy, 4) Anti-other religions, 5) Anti-Western culture and 6) Agree to use violence for achieving the goals. ${ }^{11}$ Meanwhile, Oliver Roy defines Islamism as the new name of Modern Islamic politics that wants to create an Islamic society (Ummah) and Islamic countries through political actions and enforces the formalization of Islamic sharia. ${ }^{12}$

In Indonesia, Islamism existed long before independence. However, when the New Order operated illegally and since the reformation era, Islamism has gained space to exist and develop until it is legally included in political parties ${ }^{13}$ In Egypt, the Islamist group shifted their strategy from Salafi preaching to political preaching ${ }^{14}$ and their movement failed to integrate their ideas in the real political domain. Failure of integration in

\footnotetext{
${ }^{10}$ Muhammad Wildan et.al. , Menanam Benih di Ladang Tandus:Potret Sistem Produksi Guru Agama Islam di Indonesia, Yogyakarta: CISForm UIN Sunan Kalijaga Yogyakarta, 2019, 6.

${ }^{11}$ Bassam Tibi , Islamism and Islam. New Haven: Yale University Press, 2012.

${ }^{12}$ Oliver Roy, Globalized Islam: The Search for a New Ummah, Columbia: Columbia University Press, 2004.

${ }^{13}$ Moch Nur Ichwan, "Islamisme, Pos-Islamisme, dan Reposisi Islam Mainstream: Sebuah Pendahuluan”, in Islamisme dan Pos-Islamisme: Dalam Dinamika Politik Indonesia Kontemporer, Moch Nur Ichwan and Muhammad Wildan (eds.), Yogyakarta: SUKA-Press-CISForm UIN Sunan Kalijaga Yogyakarta, 2019, 9-10.

${ }^{14}$ Naïma Bouras, "From Salafi Preaching to Political Preaching: Women's Turnout and the Evolution of Salafi Movements in Egypt", Gender, Volume 9, Number 1 (2017), 30-45.
} 
both political and social life fueled further exclusivism. ${ }^{15}$ The construction of meaning at the level of implementation of issues and symbols is of paramount importance when discussing Islamism. The circles of political Islam "believe that Islam must be realized symbolically in politics, while the substantive Islamic circles are in opposition to the presence of the Islamic party and the symbolization of shari'ah by the State". ${ }^{16}$ One of the ways to express their identity of piety, completion, and obedience to God is by wearing a niqab. Many niqabis are aware that they are different from nonniqabis by expressing their symbol of the completion (kaffah) of their life.

When discussing Islamism, patriarchy becomes quite relevant because Islamism movements, in general, are tough masculine politics with a heavymilitaristic pattern, security-approach, majority-authoritarian, patriarchal with strict gender segregation and demanding women submissions. One product of the patriarchal structure among the Salafi movement is that it obliges women to wear the niqab. ${ }^{17}$ Among Salafi groups, men usually have the privilege to force women to use the niqab. ${ }^{18}$ ISIS (Islamic State in Iraq and al-Sham, Islamic State of Iraq and Syria) requires its female members to wear niqab. When they occupied the city of Mosul in Iraq, ISIS required that all Mosul women wear niqab when leaving the house ${ }^{19}$. According to some Muslim women, wearing the niqab will protect them from men who

\footnotetext{
${ }^{15}$ Christina DeGregorio, "Islamism in Politics: Integration and Persecution in Egypt", $\mathrm{Al}$ Ja-mi'ah, Volume 48, Number 2 (2010), 343-64.

${ }^{16}$ Syahrir Karim, "Islamism: Expression of Political Islam and Islamic Politics in South Sulawesi”, JICSA, Volume 05, Number 02 (2016), 122.

${ }^{17}$ Ellen McLarney, "The burqa in Vogue: Fashioning Afghanistan”, Journal of Middle East Women's Studies, Volume 5, Number 1 (2009), 1-23.

${ }^{18}$ Knutilla, "Lean and Mean: Hegemonic Masculinity as Fundamentalism", in Contesting Fundamentalism, ed. by J. Jaffe, \& A. M. Watkinson Eds C. Schick. Nova Scotia: Fernwood Publishing, 2004; Noorhaidi Hasan, Laskar Jihad: Islam, Militancy, and the Quest for Identity in Post-New Order Indonesia, New York: Cornell Southeast Asia Program, 2006.

${ }^{19}$ Rukmini Callimachi, For Women Under ISIS, a Tyranny of Dress Code and Punishment (Desember 2016), https://www.nytimes.com/2016/12/12/world/middleeast/islamic-statemosul-women-dress-code-morality.html.
} 
have malevolent intentions regarding their bodies. This is in accordance with Surah Al-Azhab verse 59, which seeks to protect women from male lust. For niqabis, wearing a veil makes her feel more secure and able to live her identity as a Muslim woman. ${ }^{20}$ However, in many cases, wearing the niqab places Muslim women at the center of attention, targets of hatred, victims of stereotypes, and victims of discrimination. ${ }^{21}$ Discrimination against veiled women occurs in domestic and international spheres. In various regions in Indonesia, including big cities, Muslim women who wear the niqab still trigger negative reactions from the surrounding community. Veiled women are often associated with fanaticism toward religion, often even considered a radical Islamic group. ${ }^{22}$ As one niqabi confessed working in Central Jakarta, TSN gets a negative reaction from people who see her wearing a veil. Reactions include being thrown bottles at and yelled at words like ninja, terrorist, thief, and ghost. ${ }^{23}$ Another niqabi experienced discrimination that is commonly shared by veiled women in Indonesia, including difficulties abroad because of the long process of immigration and interrogation. They were accused or suspected of being members of terrorists, so they were closely examined, while it is forbidden to wear the veil in various companies and educational institutions, and receive words of sarcasm from others. ${ }^{24}$

\footnotetext{
${ }^{20}$ Sudrajat, Jilbab di Indonesia, Antara Pelarangan dan Perjuangan (7 Mar 2018), https://news. detik.com/berita/d-3903674/jilbab-di-indonesia-antara-pelarangan-dan-perjuangan.

${ }^{21}$ Lamya Kaddor, "Kenapa Saya Sebagai Perempuan Muslim Tidak Berjilbab”, Deutsche Welle (2018), https://www.dw.com/id/kenapa-saya-sebagai-perempuan-muslim-tidakberjilbab/a-43418026.

${ }^{22}$ Resti Amanda \& Mardianto, "Hubungan Antara Prasangka Masyarakat Terhadap Muslimah Bercadar Dengan Jarak Sosial”, Jurnal RAP UNP, Volume 5, Number 1 (2014), 72-81.

${ }^{23}$ Amanda Siddharta, Mengapa Niqab (Makin) Banyak Digunakan oleh Wanita Muslim di Indonesia (20 Feb 2018), https://www.matamatapolitik.com/mengapa-niqab-banyakdigunakan-oleh-wanita-muslim-di-indonesia/.

${ }^{24}$ Dwi Retno Cahyaningrum \& Dinie Ratri Desiningrum, "Jiwa-Jiwa Tenang Bertabir Iman: Studi Fenomenologi Pada Mahasiswi Bercadar di Universitas Negeri Umum Kota Yogyakarta”, Jurnal Empati, Volume 7, Number 3 (2017), 278-96.
} 


\section{Debate on covering aurat}

In the beginning, the emancipation of women through education sparked controversy, which has still lingered because it pushes further to the question of other rights, such as working, leadership, and refusing polygamy. More problematic is the issue of women's outfits in all its forms, starting from the headscarf (jilbab) in the early 1980s to the niqab today. The main issue is not merely a matter of how women choose it but a movement that is driven by religious ideology or the so-called Islamism, which usually contests against the existing government and mainstream social system. Roy argues that Islamism is not resurfacing in order to rescue the religious decline but obviously responding to the crisis between religion and politics and religion with the state and the fragmentation of religious identity and authority. ${ }^{25}$ In such instability and social unrest, women and minority groups are the vulnerable target.

Hijab was eventually accepted in the early 1980s. With a harmonious modification and adjustment, it revealed a new identity of modern-Muslim women coupled with a modern outfit such as fashional long skirts and pants. Niqab seems to take a similar road considered the continuum of hijab in order to obtain the perfection of piety. ${ }^{26}$ Hijab and modern outfit have become not sufficient enough to represent the true Islamic woman in the last 20 years or so. Hijab in the form of a scarf covering the head, beautifully wrapped around the neck with fancy accessories and in harmony with charming facial makeup, started to be extended and loosely covered the chest with dark and gloomy colors of black, dark blue, and dark brown without makeup. This is what came to be referred to as "Syar' 1 Jilbab" (More Islamic hijab) against the fashionable veil. Moreover, in the

\footnotetext{
${ }^{25}$ Oliver Roy, Islam: A Passage to the West: Globalized Islam: The Search for A New Ummah, London: Hurst and Company, 2002, 2-4.

${ }^{26}$ Alimatul Qibtiyah, Hijab in Indonesia: The History and Controversies, The Conversation (2019), The Conversation http://theconversation.com.
} 
last 10 years, the Syar'i Jilbab has eventually been considered an imperfect Islamic garment because it still displays the face, which is believed to be a female's sexual attraction.

In fact, there is a loose definition of covering the body in Islam. Covers range from fashionable veil, long-veil, and niqab, which is constantly debated among Islamic scholars. The leading Indonesian scholars Quraisy Syihab, Al Azhar graduate, argued that covering the body in Islam is contextual depending upon the social acceptance of modesty and refinement. Traditional or national outfits usually worn by the Indonesian leading women without covering the head do not substantially conflict with religious teachings. ${ }^{27}$ There are also Egyptian scholars, such as Hamdallah Hafidz al Shafty, Director of the Office of Culture and International Alumni Association, Al Azhar University, Cairo Egypt, who argues that there was no such a single standard of the Muslim outfits even in the time of the Prophet where many kinds of clothing from Rome, Persia, and Coptic tradition were found ${ }^{28}$. Nowadays, fashionable hijab is widely accepted as the moderate expression of Islamic outfit but long-loose Jilbab and niqab have envoked controversies not only in the West but also in Muslim countries like Indonesia and Egypt. The reaction toward niqab seems to be more obvious than the hijab; the Egyptian government has recently announced to plan banning niqab in the public places for security reasons as well as the prevention of extremism and terrorism, which are the country's dauting issues. ${ }^{29}$ There are at least 10 coutries including some

${ }^{27}$ Quraish Shihab, Wawasan al-Qur'an: Tafsir Mawdhu'i atas Berbagai Persoalan Umat, Bandung: Mizan, 1996, 179; Quraish Shihab, Tafsir Al-Misbah: Pesan, Kesan dan Keserasian al-Qur'an Jakarta: Lentera Hati, cetakan 6, Jilid 5 dan 9, 2006, 332-4.

${ }^{28}$ Hamdallah Hafidz Al Shafty, interview (1 Oct 2018).

${ }^{29} \mathrm{Amr}$ Emam, Battle of the niqab moves to Egypt: Lawmakers are seeking to link a ban to security concerns, not wider political or social issues. (2018), https://thearabweekly.com/battle-niqabmoves-egypt. 
Muslim-majority countries where women are not allowed to wear niqab. ${ }^{30}$

Indonesia has been struck by the rapid growth of niqab along with the new trend of "hijrah" (moving) among celebrities guided by some newly returnist scholars from Middle East universities suspected to have strong affiliations with Islamic hardliners, such as Hizbu Tahrir (the Army of liberation), Ichwanul Muslimin, or even the Extremist supporters of ISIS and other similar ones. Those groups have been known as Salafi (conservative) in religious thought-an Islamist group, whose main political ideology and mission are the establishing of the so-called "Islamic State," of which Iran is being the role model or reviving "caliphate"-the medieval type of statehood. Islamism has been loosely characterized with cultural purification, Islamic formality, anti-democratic system, intolerance to religious differences, being anti-Western, and adopting violence as a means to gain power. ${ }^{31}$ Those groups believe that the power of Islam should be assembled and united as a single political entity around the world from Marrocco from west of Africa to Indonesia in the East.

The niqab has been formally banned by the State Islamic University Sunan Kalijaga Indonesia in 2017, which sparked debates among Islamic organizations, Islamic scholars, as well as human right activists who argued that niqab should be seen as freedom of expression and freedom of religion guaranteed by the International Convention of Civil and Political Rights (ICCPR) of the United Nations. ${ }^{32}$ The university proceeds in prohibiting the niqab on the campus and during the learning process in the classroom according to the university regulation of student affairs: "Female student shall observe the modest outfit which is not too tight and transparence,

${ }^{30}$ Alex, P. Schmid, "Moderate Muslims and Islamist Terrorism: Between Denial and Resistance", The Hague, Volume 8, Number 9 (2017): 1-28.

${ }^{31}$ Bassam Tibi , Islamism and Islam, New Haven: Yale University Press, 2012.

${ }^{32}$ Ainun Najib, "Larangan Bercadar di UIN Yogyakarta Menuai Protes”, SindoNews. Com, http//derah.sindonews.com, downloaded 12 December 2018. 
open face during the learning process as well as activities at the university." ${ }^{33}$ The ban of niqab in that university is regarded as a pioneer and valiant act for defending its mission as the guard of Islamic moderation, which aims at integrating and interconnecting between Islamic tradition and modern science in order to make Islam responsive and compatible with the rapid social transformation. Niqab is, therefore, seen to conflict with moderation and advocating conservatism and extremism, which is no ground in the teaching of Islam.

The social response is equally appalling where many parents were shocked to find that their daughters decided to observed niqab without their consent. It brought a kind of social pressure onto the families in the neighborhood as it was stigmatized as being connected to ISIS and terrorist groups ${ }^{34}$. A similar reaction was documented by Susan Brenner when jilbab started as a new trend of Islamization and was somehow linked to fanatism or, as it is politically known, 'right extremism' as opposed to 'leftist extremism' in the New Order regime in 1980an ${ }^{35}$ Nisa noted that the parent's concern on niqab:

Includes their assumption that wearing the cadar may hinder their daughter's future career and marriage prospects. One important difference from previous objections to wearing the jilbab is the issue of terrorism. This is linked to the stigma around cadari (not jilbaber or a woman who wears a jilbab) in Indonesia according to which they are considered as potential terrorists or part of terrorist networks. Therefore, parents usually ask their daughters not to wear the cadar when they return home to the kampung

${ }^{33}$ UIN Sunan Kalijaga Yogyakarta, Tata Tertib Mahasiswa, UIN Sunan Kalijaga Yogyakarta, 2018, 10.

${ }^{34}$ Eva Nisa, "Embodied Faith: Agency and Obedience among Face-veiled University Students in Indonesia”, The Asia Pacific Journal of Anthropology, Volume 13, Number 4 (2012), 366-381.

${ }^{35}$ Susan Brenner, "Reconstituting Self and Society: Javanese Muslim Women and The Veil”, American Ethnologist, Volume 4, Number 23 (1996), 673-697. 
(village) to prevent rumours. The most difficult moment for many parents is when their daughter asks their permission to quit university because the faculty does not accept wearing the cadar. ${ }^{36}$

Indonesia is a country with a Muslim majority population, but it took a long time for the hijab (Indonesia call jilbab) to be accepted willingly in society. Jilbab was a debate in Indonesia in the period 1970-1980. Some schools banned on wearing headscarves for students as stipulated in Decree 052/C/Kep/D.82 concerning National School Uniforms on March 17, 1982. In the early 1990s, demonstrations rejected the ban on veiling in schools and campuses at many prominent universities in big cities. These demonstrations encouraged the New Order government at that time to further soften its political policies toward Muslims, until February 16, 1991, a Decree No. 100/C /Kep/D/1991 was published, allowing students to wear clothes based on their beliefs ${ }^{37}$. The rules regarding covering up the aurat for women are contained in many verses of the Qur'an. One of the most famous is QS. Al Ahzab verse 59, where the covering of the female aurat is referred to as the "hijab. ${ }^{3} 8$

Scholars have a variety of interpretations on this verse when it is associated with Islamic clothing and the completion (kaffah). The first group interpreted that the entire female body, including face and hands, must be covered (Abul A'la al Maududy, Ibnu Abbas). The second group agued that the face and hands of Muslim women do not need to be covered (Imam Syafi'i). The third group interpreted that the face, hand, and what usually looks like feet for the Indonesian context do not need to be covered (Tarjeh Muhammadiyah). While the fourth group emphasized that the

\footnotetext{
${ }^{36}$ Eva Nisa, "Embodied Faith"..., 372.

${ }^{37}$ Sudrajat, Jilbab di Indonesia, Antara Pelarangan dan Perjuangan 7 Mar 2018, https://news. detik.com/berita/d-3903674/jilbab-di-indonesia-antara-pelarangan-dan-perjuangan.

${ }^{38}$ Kementrian Agama RI, Terjemahan Al Qur'an Surat Al Ahzab ayat 59, 2019, https:// quran.kemenag.go.id/.
} 
important thing is to dress modestly in accordance with local culture, not having to cover their head/hair, let alone face (Quraish Shihab).

In some Islamic countries, the following terms are often used in reference to female aurat: 1) burqa, which is a garment that covers a woman's entire body, including the palms and face, and the eyes are also covered by a thin-visible piece of cloth, usually worn by women in Afghanistan and some parts of Pakistan; 2) niqab, which is the covering of the entire body and face except the eyes-also known as the cadar in Indonesia; 3) chador, which is an Iranian and Pakistani traditional garment in the form of a loose robe covering the entire body except the face; 4) hijab/jilbab, which is a headcover that is separate from the other clothes, functions as a cover for the head, neck, and part of the chest-common in Indonesia under the name 'hijab.' Among Indonesian Muslim women, the terms are still added with: 5) veil/selendang, which is a scarf wrapped around the head that partially covers the hair and ears; and 6) long headscarves, namely clothes that are similar to the hijab brackets but are much longer and loose. ${ }^{39}$

According to Saba Mahmood, women's veiling is an expression of piety. ${ }^{40}$ In the Indonesian context, Dewi Chandraningrum ${ }^{41}$ found that veiling is not only related to religion but also to politics, economy, and sexuality. Eva F. Nisa reveals that niqabis among university students struggle to reconstruct their religious identity and their capacity for exercising a specific type of religious agency. ${ }^{42}$ Furthermore, she found that parents are worried about their daughters' decision to wear niqab. The veil is considered a modern construct evolving from a political and

\footnotetext{
${ }^{39}$ Atikah Syazwani, Hijab, Burqa dan Niqab, April 2016, https://atikahsyazwani98. wordpress.com/2016/04/05/180/.

${ }^{40}$ Saba Mahmood, Politic of Piety: The Islamic Revival and the Islamic Subject, Princeton: Princeton University Press, 1962.

${ }^{41}$ Dewi Chandraningrum, Negotiating Women's Veiling, Politic $\mathcal{E}$ Sexulaity in Contemporary Indonesia, Bangkok: RASEC, 2013.

${ }^{42}$ Eva Nisa, Embodied Faith"..., 372.
} 
legal jurisdiction which covers diverse ethnicities, faiths, and cultures. It is the subject of contestation and negotiation. Identity is in 'the constant making. ${ }^{43}$ Gramsci in Larrain ${ }^{44}$ argued that collectiveness could be strongly upheld by a coercive measure or a hegemonic dominance, but will abruptly collapse.

Conducted in early 2019 in Egypt and Indonesia, this research has aimed at exploring the personal views of women observing niqab in the rise of its trends following the revival of Islamism on the global scale. It combines qualitative and quantitative methods. Data were collected from closed-ended questionnaires, life stories, semi-structured interviews, and focus group discussions (FGD). Selective memory and the synthesizing nature of life stories lead us beyond facts to their meanings, which are particularly useful in studies of worldview ${ }^{45}$. The life stories used here cover entire life-spans and additionally deal with more thematic issues relating to religion and niqab. The research procedure included framing and identifying a theoretical framework, developing research instruments, collecting data, reporting findings, and disseminating results. This research was conducted over a period of six months and its respondents represent niqabis, the elites in the government and civil society, and religious and cultural leaders from two countries, Indonesia and Egypt. This research was conducted collaboratively with the Dominican Institute for Oriental Studies in Cairo, Egypt. Closed-ended questionnaires and life stories were used to explore the motives, thought, and normative work relating to niqab and the ideal Muslim woman's dress for Niqabis. Semi-structured interviews were used for the government and civil society elites and religious and cultural leaders in the two selected countries. Focus group discussions were

\footnotetext{
${ }^{43}$ Bikhu Parekh, A New Politic of Identity: Political Principles for an Interdependent World, New York: Palgrave Macmillan, 2008.

${ }^{44}$ Jorge Larrain, The Concept of Ideology, London: Hutchinson Publication, 1979.

${ }^{45}$ Furseth Inger, From Quest for Truth to Being Oneself, Frankfurt am Main: Peter Lang, 2006.
} 
implemented with civil society groups such as Islamic mass organizations and universities in Indonesia (Nahdatul Ulama, Muhammadiyah, Islamic State University). A total of 292 Niqabis participated (87 from Cairo and 205 from Indonesia-Yogyakarta, NTB, Lampung, Surabaya, and IndonesiaCairo). There were 27 niqabis selected to sit for in-depth interviews using the life story technique (Cairo 6, Indonesia 14). A number of 23 figures participated in interviews and FGDs (6 Cairo, 17 Indonesia), including politicians, women activists, academics, government employees, and religious leaders. Data were analysed using Miles and Huberman interactive model: data condensation, data display, drawing and verifying conclusion ${ }^{46}$. To keep respondents' confidentiality, all niqabis' names mentioned in this report have been changed.

\section{Level of Islamism and Nationalism of niqabis in Indonesia and Egypt}

This study reveals two aspects of nationalism, namely citizenship belongingness and objection against democracy and three aspects of Islamism, including adopting Islamic caliphate and Islamic monetary system as well as supporting violence in defending religion. One important negative issue that is sometimes experienced by niqabis is the accusation that they are part of a terorrist network. The following findings are explained based on quantitative and qualitative data both from niqabis and prominent figures in Egypt and Indonesia.

Nationalism: level of citizenship belongingness and objection against democracy

Based on the quantitative data obtained, it is highlighted that most niqabis demontrated their belonging to their motherland. The majority

\footnotetext{
${ }^{46}$ Matthew B. Miles, A.M. Huberman, and Johnny Saldaña, Qualitative Data Analysis: A Methods Sourcebook, Washington DC: SAGE, 2014.
} 
of respondents, both in Egypt and Indonesia, declared they were proud of being citizens in their countries. Table 1 explains that in Egypt, $89.65 \%$ of niqabis are proud to be Egyptian and only 3.4\% say otherwise. Likewise, $70.73 \%$ of Indonesian niqabis stated that they were proud to be Indonesian citizens, which means that 1 out of 3 Indonesian niqabis is not proud to be Indonesian citizens.

Zia, a student in Yogyakarta, Indonesia, said that she was very proud of Indonesia: "If I was told to choose where I want to come from, I still chose Indonesia." ${ }^{47}$ The same thing was declared by Maye, a student at Al-Azhar University in Cairo, Egypt:

I'm very proud to be an Egyptian. Whatever happens I remain proud of being an Egyptian. no one can tear my pride. Egypt is the land of the prophets, Egypt is also referred to in the Quran. Egypt is the violin of God. In Egypt there is "Sina" the place where prophet Moses spoke with God. It's also a beautiful place. ${ }^{48}$

Table 1 Pride to be A Citizen

\begin{tabular}{lll}
\hline \multicolumn{1}{c}{ Answer } & \multicolumn{1}{c}{ Egypt $(\mathbf{n}=87)$} & Indonesia $(\mathbf{n}=205)$ \\
\hline No Answer & 6.9 & 2.9 \\
Yes & 89.7 & 70.8 \\
No & 3.4 & 26.3 \\
\hline Total & 100.0 & 100.0 \\
\hline
\end{tabular}

Nowadays, it is commonly considered by the general public that those who wear niqab are closely related to radical mindsets and political views that reject democracy. The second indicator that reflects nationalism is the perception that the government system is thaghut. Thaghut literally

\footnotetext{
${ }^{47}$ Zia, interview (22 Nov 2018).

${ }^{48}$ Maye, interview (29 Oct 2018).
} 
means "exceed the limit." This is a term in Islam that refers to anyone who worships other than Allah and someone who obeys those who disobey Allah's commands ${ }^{49}$. Thaghut government is a system of government based on laws and other rules that are man-made and do not originate directly from the Quran, Hadith, Ijma', and Qiyas. Table 2 hilghlited that the majority of the respondents do not consider that the government is thaghut. Egyptian Niqabis who agreed to this matter were $36.8 \%$, which is slightly different from those who rejected the opinion-39.1\%. In Indonesia, more than half of the niqabis $(55.6 \%)$ do not consider the government to be a thaghut, while the other $39 \%$ justify this assumption.

Table 2 The Government is Thaghut

\begin{tabular}{lcc}
\hline \multicolumn{1}{c}{ Answer } & Egypt $(\mathbf{n}=\mathbf{8 7})$ & Indonesia $(\mathbf{n}=\mathbf{2 0 5})$ \\
\hline No Answer & 24.1 & 4.9 \\
Strongly Disagree & 23.0 & 15.6 \\
Disagree & 16.1 & 40.0 \\
Agree & 13.8 & 30.7 \\
Strongly Agree & 23.0 & 8.8 \\
\hline Total & 100.0 & 100.0 \\
\hline
\end{tabular}

Islamism: monetary system, caliphate, exhorting violence in defending religion

Islamism in this research can be revealed by the attitude toward the Islamic monetary system, Islamic caliphate, and violence in defending religion. As Bassam Tibi ${ }^{50}$ explained that one of the indicators of Islamism is the

\footnotetext{
${ }^{49}$ Adika Mianoki, Siapakah Thaghut? (2013), https://muslim.or.id/11364-siapakah-thaghut. html.

${ }^{50}$ Bassam Tibi, Islamism and Islam, New Haven: Yale University Press, 2012.
} 
rejection of the goverement system, including what is related to financial issues, particularly bank interests. Regarding bank interests, the majority of respondents agree that bank interest is haram (forbidden in Islam). This was agreed by $78.2 \%$ of Egyptian niqabis and $87.3 \%$ of Indonesian niqabis. Only 14.9\% from Egypt and 11.2\% from Indonesia declared that bank interest was acceptable (see Table 3).

Tabel 3 Bank interest is haram

\begin{tabular}{lcc}
\hline \multicolumn{1}{c}{ Answer } & Egypt $(\mathbf{n}=87)$ & Indonesia $(\mathbf{n}=\mathbf{2 0 5})$ \\
\hline No Answer & 6.9 & 1.5 \\
Strongly Disagree & 6.9 & 3.4 \\
Disagree & 8.0 & 7.8 \\
Agree & 20.7 & 33.7 \\
Strongly Agree & 57.5 & 53.6 \\
\hline Total & 100.0 & 100.0 \\
\hline
\end{tabular}

Discussions on supporting the Islamic caliphate in Indonesia and in Egypt are always connected with the propaganda of Hizb al-Tahrir (HT). The idea of caliphate was promoted by Hizb al-Tahrir (HT), an international political organization based in Palestine. Even though this organization has been banned in both Egypt and Indonesia, the ideology of the caliphate spread by HT still feels resonant. A prominent figure in Lombok, a lecturer at UIN Mataram as well as the Muhammadiyah Regional Leadership in Lombok, said that HTI women must wear the niqab and be ready to have a polygamous marriage, as part of the customs and agreements in that organization. ${ }^{51}$ While Jumarim, a lecturer from UIN Mataram, gave additional information that female HT members were mostly niqabis and

\footnotetext{
${ }^{51}$ Sabain, interview, 17 Nov 2018.
} 
Islamic caliphate must be formed. ${ }^{52}$ One female activist, also a lecturer at UIN Mataram, Atun Wardatun, stated that: "Some people see niqabis clothing as radical clothing...They generally support to caliphate system... Not worrying about her veil, but worrying about the ideology ".53

It can be understood from Table 4 that niqabis from Egypt, $59.8 \%$ of respondents agree that Islam can only be upright with the caliphate system, while $23 \%$ reject the caliphate system. The same pattern also happened to Indonesian niqabis where $51.7 \%$ agree on the caliphate system, while $44.9 \%$ expressed their disapproval. The discussion about caliphate is usually in line with the discussion about the violent extremism allowed for defending religion.

Niqabis from both countries refuse exhorting violence in the name of religion. Around $86.2 \%$ of Egyptian niqabis and $84.8 \%$ of Indonesian niqabis oppose the use of violence in defense of religion. Although they want the establishment of a caliphate on earth, violence is not considered an appropriate way of defending religion.

Tabel 4 Niqab and Politic Ideology

\begin{tabular}{lcccc}
\hline \multirow{2}{*}{ Answer } & \multicolumn{2}{c}{$\begin{array}{c}\text { Islam is only upright with } \\
\text { the Caliphate }\end{array}$} & \multicolumn{2}{c}{$\begin{array}{c}\text { Violence for } \\
\text { defending religion }\end{array}$} \\
\cline { 2 - 5 } & $\begin{array}{c}\text { Egypt } \\
(\mathbf{n}=87)\end{array}$ & $\begin{array}{c}\text { Indonesia } \\
(\mathbf{n}=205)\end{array}$ & $\begin{array}{c}\text { Egypt } \\
(\mathbf{n}=87)\end{array}$ & $\begin{array}{c}\text { Indonesia } \\
(\mathbf{n}=205)\end{array}$ \\
\hline No Answer & 17.2 & 3.4 & 4.6 & 1.0 \\
Strongly Disagree & 6.9 & 8.8 & 71.3 & 46.8 \\
Disagree & 16.1 & 36.1 & 14.9 & 38.0 \\
Agree & 26.4 & 34.7 & 6.9 & 10.3 \\
Strongly Agree & 33.4 & 17 & 2.3 & 3.9 \\
\hline Total & 100.0 & 100.0 & 100.0 & 100.0 \\
\hline
\end{tabular}

\footnotetext{
${ }^{52}$ Jumirin, interview, 17 Nov 2018.

${ }^{53}$ Atun Wardatun, interview, 17 Nov 2018.
} 
The relation between Indonesian and Egyptian niqabis and the transnational movement, which has a political agenda, can be explained by the time niqabis started wearing niqab. ISIS started influencing Indonesian Muslims in 2013-2014. ${ }^{54}$ There is a significant difference in the ages of Egyptian and Indonesian respondents regarding when they started wearing the niqab. In Table 5, in Egypt, most started wearing niqab in their teenage, which is $10-15$ years $(42.5 \%)$ and others, when they were $16-21$ years old (41.3\%). Indonesia, on the other hand, where the niqab is a recent phenomenon, $65 \%$ of respondents wore the niqab in early adulthood, which is $16-21$ years. The majority of Indonesian respondents claimed they started wearing the niqab in the last four years, amounting to $84.2 \%$. Egyptian women who have just worn the niqab from 2015 onwards represent $50 \%$.

Tabel 5 Age started wearing niqab

\begin{tabular}{lcc}
\hline \multicolumn{1}{c}{ Answer } & Egypt $(\mathbf{n}=\mathbf{8 7})$ & Indonesia $(\mathbf{n}=205)$ \\
\hline No Answer & 12.6 & 18.5 \\
$10-15$ & 42.5 & 7.8 \\
$16-21$ & 41.3 & 65 \\
$>21$ & 4.5 & 8.7 \\
\hline Total & 100.0 & 100.0 \\
\hline
\end{tabular}

\section{Niqabis is not terrorist}

Niqabis in Indonesia often suffered from being labeled and suspected of having ties with terrorist groups. As previously mentioned by Nisa, the difference between Hijab and Cadar is the issue of terrorism..$^{55}$ One

\footnotetext{
${ }^{54}$ Indra Wijaya, "Bagaimana ISIS Masuk Indonesia?", tempo.co (2014), https://nasional. tempo.co/read/596975/bagaimana-isis-masuk-indonesia/full\&view=ok.

${ }^{55}$ Eva Nisa, "Embodied Faith”..., 372.
} 
community leader in Lombok said, "Not all niqabis are terrorists, amid all captured terrorists' wives are wearing niqab". ${ }^{56}$ The same opinion stated by one of the parliement members in Egypt was that there is no direct connection between niqabis and terrorists, albeit the exclusive Islamic views among them. ${ }^{57}$ The majority of niqabis interviewed, both Egypt and Indonesia, argue that the stigma that "niqabis are terrorists" is not true. They also deny the assumption that niqab is exclusively observed by women with terrorist connections. It can be explained in Table 6 that only $1.1 \%$ of Egyptian niqabis and $1.5 \%$ of Indonesian niqabis agree that niqab is often associated with terrorism.

Tabel 6 Niqab and Terrorism

\begin{tabular}{|c|c|c|c|c|}
\hline \multirow[t]{2}{*}{ Answers } & \multicolumn{2}{|c|}{$\begin{array}{c}\text { The Different between } \\
\text { Niqabis and Hijaber is } \\
\text { Extremist Ideology }\end{array}$} & \multicolumn{2}{|c|}{$\begin{array}{l}\text { Terrorist Women Wear } \\
\text { Niqab }\end{array}$} \\
\hline & $\begin{array}{l}\text { Egypt } \\
(\mathrm{n}=87)\end{array}$ & $\begin{array}{c}\text { Indonesia } \\
(\mathrm{n}=205)\end{array}$ & $\begin{array}{l}\text { Egypt } \\
(\mathrm{n}=87)\end{array}$ & $\begin{array}{c}\text { Indonesia } \\
(\mathrm{n}=205)\end{array}$ \\
\hline No Answer & 3.4 & 4.9 & & \\
\hline Strongly Disagree & 63.2 & 40.5 & 88.5 & 79.0 \\
\hline Disagree & 27.6 & 46.8 & 10.3 & 19.5 \\
\hline Agree & 1.1 & 5.9 & 1.1 & 1.5 \\
\hline Strongly Agree & 4.6 & 2.0 & & \\
\hline Total & 100.0 & 100.0 & 100.0 & 100.0 \\
\hline
\end{tabular}

Similarly, the niqabis object the perception that the main distinction between observing niqab and the fashionable hijab is the extreme ideology as previously concluded by Eva. As many as $90.8 \%$ of Egyptian and $87.3 \%$

\footnotetext{
${ }^{56}$ Jumirin, interview, 17 Nov 2018.

${ }^{57}$ Muhammad Abu Hamid, interview, 5 Nov 2018.
} 
of Indonesian respondents confirm such a misjudgment. One of the leaders at fatwa council (Darul Ifta) in Egypt, explained:

Someone who thinks that wearing a niqab is terrorist is wrong ... if there is a police officer who catches a woman suspected of being terrorist not because she is wearing a niqab but because there are other evidence. ${ }^{58}$

This view might be equally shared by religious figures in Indonesia but many of them admitted that Niqab, especially the dark full cover, might be easily associated with terrorism because such an outfit was captured by media when jihadist groups were arrested by the police. Besides, covering women's full body is the core of the doctrines among those groups. ${ }^{59}$

\section{Conclusion}

The conclusion that can be derived from the research findings concerns the bodily control embedded in the personal autonomy of the feminist narrative and how it is fiercely challenged by the fact that women in Egypt and Indonesia observed the Niqab in their own personal choices. In addition, their objection to being associated with terrorism and the stigma of being opposed to modernity poses another challenge. This is described in Mernissi's account as the veil typifying a manifestation of misogyny that curbs women's enjoyment of their rights and public participation. Moreover, As indicated by Jayawardena, the Muslim world turned to democracy and nation state in the post-colonial era, which entailed the concept of nationalism and governance. The research indicates that the view on nationalism measured from the pride of citizenship and the aspiration of the caliphate system varies. The caliphate system, as the core political struggle for the Islamists, accepted only 52\% in Indonesia and $59 \%$ in Egypt, which is lower than the common expectation that those

\footnotetext{
${ }^{58}$ Mukhtar Muhsin, interview, 4 Nov 2018.

${ }^{59}$ Abdur Rozaki, interview, Oktober 2018.
} 
groups would be able to score the highest. The degree of nationalism, which is measured by citizens' pride of citizenship, reveals promising results. Only 20\% of the Indonesian, and 3\% of the Egyptian, niqabis expressed their dissatisfaction and declared they were not proud of being citizens of their countries. It means that $80 \%$ to $97 \%$ of them still hold their strong nationalism, albeit their aspiration for the adoption of the caliphate system, which is just above $50 \%$.

Furthermore, the response to governance measured from the acceptance of the existing government and economic system is fragmented where the acceptance is around $60-73 \%$ to the existing government in contrast to those who view it as thaghut or not in accordance with the Islamic political principles-37 \% in Egypt and 40\% In Indonesia. The economic system measured from the bank interest reveals the highest response of $87 \%$ in Indonesia and $79 \%$ in Egypt. The objection of exhorting violence in the name of religion for a political end is very high in this group in both countries, which is a strong indication for the unwillingness to associate themselves with terrorism.

The theoretical contributions of this research are placed within the feminist concept of 'the personal is political' and the concept of nationalism. The increasing numbers of women observing the Niqab while engaging in public activities can be the challenge of the initiated concept of 'the personal is political' where, in the past, women needed to dismantle the misogynic tradition. This is a tradition in which, Mernissi observes, the veil or niqab is rooted. In addition, the classic nationalism based on secularization poses the substantial challenge on how to adopt religious values in a democracy and economic system. To what extent does democracy accommodate religious values in its core system of inclusivity, protection of human rights, multiculturalism, and pluralism in the attempt to curb the aspiration of the caliphate system, which is theocratic and 
exclusive in its nature.

This study proposes two recommendations for further research on how to negotiate the personal autonomy as the core of the concept of " the personal is political' to the present rise of niqabism while safeguarding democracy and nationalism, which are believed to be the plausible political systems respecting diversity and individual rights vis-a-vis the caliphate system. Equally critical is how to benchmark the concept and the practice in how a religious-inspired political system is plausible without undermining the core democratic values, which prove plausible in managing nationalism in the plural and multi-cultural context.

\section{Bibliography}

Amanda, Resti \& Mardianto, "Hubungan Antara Prasangka Masyarakat Terhadap Muslimah Bercadar Dengan Jarak Sosial”, Jurnal RAP UNP, Volume 5, Number 1 (2014): 72-81.

Bouras, Naima, "From Salafi Preaching to Political Preaching: Women's Turnout and the Evolution of Salafi Movements in Egypt", Gender, Volume 9, Number 1 (2017): 30-45.

Brenner, Susan. "Reconstituting Self and Society: Javanese Muslim Women and The Veil”, American Ethnologist, Volume 4, Number 23 (1996): 673-97.

Cahyaningrum, R. Dwi \& Desiningrum, Dinie Ratri, "Jiwa-Jiwa Tenang Bertabir Iman: Studi Fenomenologi Pada Mahasiswi Bercadar di Universitas Negeri Umum Kota Yogyakarta”, Jurnal Empati, Volume 7, Number 3 (2017): 278-96.

Callimachi, Rukmini. For Women Under ISIS, a Tyranny of Dress Code and Punishment, Desember 2016, https://www.nytimes.com/2016/12/12/ world/middleeast/islamic-state-mosul-women-dress-code-morality.html.

Chandraningrum, Dewi. Negotiating Women's Veiling, Politic $\mathcal{E}$ Sexulaity in Contemporary Indonesia. Bangkok: RASEC, 2013.

DeGregorio, Christina, "Islamism in Politics: Integration and Persecution in Egypt", Al Ja-mi'ah, Volume 48, Number 2 (2010): 343-64.

Emam, Amr. Battle of the niqab moves to Egypt: Lawmakers are seeking to link a ban to security concerns, not wider political or social issues, 2018, https:// thearabweekly. com/battle-niqab-moves-egypt. 
Gouveia, Lexandra, 10 Countries Where Women Are Forbidden To Wear The Veil, Jul 2017, https://emirateswoman.com/10-countries-women-forbiddenwear-veil/.

Hasan, Noorhaidi. Laskar Jihad: Islam, Militancy, and the Quest for Identity in PostNew Order Indonesia. New York: Cornell Southeast Asia Program, 2006.

Hanich, Carol, The Personal is Political, www.carolhanisch.org downloaded 22 february 2019.

Ichwan, N. Moch., "Islamisme, Pos-Islamisme, dan Reposisi Islam Mainstream: Sebuah Pendahuluan”, in Islamisme dan Pos-Islamisme: Dalam Dinamika Politik Indonesia Kontemporer, ed. by Moch Nur Ichwan and Muhammad Wildan. Yogyakarta: SUKA-Press-CISForm UIN Sunan Kalijaga Yogyakarta, 2019.

Inger, Furseth. From Quest for Truth to Being Oneself. Frankfurt am Main: Peter Lang, 2006.

Jayawardena, Kumari. Feminism and Nationalism in The Third World: In The 19th and Early 20th Centuries. The Hague: Institute of Social Studies, 1982.

Karim, Syahrir, "Islamism: Expression of Political Islam and Islamic Politics in South Sulawesi”, JICSA, Volume 05, Number 02 (2016): 121-35.

Kementrian Agama RI, Terjemahan Al Qur'an Surat Al Ahzab ayat 59, 2019, https:// quran.kemenag.go.id/.

Knutilla, "Lean and Mean: Hegemonic Masculinity as Fundamentalism", in Contesting Fundamentalism, ed. by J. Jaffe, \& A. M. Watkinson Eds C. Schick. Nova Scotia. Fernwood Publishing, 2004.

Kaddor, Lamya, "Kenapa Saya Sebagai Perempuan Muslim Tidak Berjilbab", Deutsche Welle, 2018, https://www.dw.com/id/kenapa-saya-sebagaiperempuan-muslim-tidak-berjilbab/a-43418026.

Larrain, Jorge. The Concept of Ideology. London: Hutchinson Publication, 1979. Mahmood, Saba. Politic of Piety: The Islamic Revival and the Islamic Subject. Princeton, The United Kingdom: Princeton University Press: Princeton University Press, 1962.

Mernissi, Fatima. The Veil and The Male Elite; A Feminist Interpretation of Women's Rights in Islam. New York: Persues Book Publications.

McLarney, Ellen, "The burqa in Vogue: Fashioning Afghanistan", Journal of Middle East Women's Studies, Volume 5, Number 1 (2009): 1-23.

Miles, Matthew B., Huberman, A.M., and Saldaña, Johnny. Qualitative Data Analysis: A Methods Sourcebook. Washington, DC: SAGE, 2014.

Millett, Kate. Sexual Politics. Urbana: University of Illinois Press, 1970.

Mianoki, Adika. Siapakah Thaghut?, 2013, https://muslim.or.id/11364-siapakahthaghut.html. 
Naim, Abd Allah Ahmad, Islam and the Secular State: Negotiating the Future of Sharia, Massachussets, USA: Harvard University Press, 2008.

Najib, Ainun, "Larangan Bercadar di UIN Yogyakarta Menuai Protes", SindoNews. Com, http//derah.sindonews.com, downloaded 12 December 2018.

Nisa, Eva, "Embodied Faith: Agency and Obedience among Face-veiled University Students in Indonesia," The Asia Pacific Journal of Anthropology, Volume 13, Number 4 (2012): 366-81.

Parekh, Bikhu. A New Politic of Identity: Political Principles for an Interdependent World. New York: Palgrave Macmillan, 2008.

Qibtiyah, Alimatul. Hijab in Indonesia: The History and Controversies. The Conversation, 2019, The Conversation http://theconversation.com.

Ratri, Lintang, "Cadar, Media, dan Identitas Perempuan Muslim", Jurnal FORUM Universitas Diponegoro, Volume 39, Number 2 (2011): 29-37.

Rogan, Frances and Budgeon, Shelley, "The Personal is Political: Assessing Feminist Fundamentals in the Digital Age”, Journal of Social Science, Volume 7, Number 132 (2008): 1-19.

Roy, Oliver. Islam: A Passage to the West: Globalized Islam: The Search for A New Ummah. London: Hurst and Company, 2002.

Roy, Oliver. Globalized Islam: The Search for a New Ummah. Columbia: Columbia University Press, 2004.

Schmid, P. Alex, "Moderate Muslims and Islamist Terrorism: Between Denial and Resistance", The Hague, Volume 8, Number 9 (2017): 1-28 [http:// dx.doi.org/10.19165/2017.1.09].

Siddharta, Amanda, Mengapa Niqab (Makin) Banyak Digunakan oleh Wanita Muslim di Indonesia, 20 Feb 2018, https://www.matamatapolitik.com/mengapaniqab-banyak-digunakan-oleh-wanita-muslim-di-indonesia/.

Syazwani, Atikah. Hijab, Burqa dan Niqab, Apr 2016, https://atikahsyazwani98. wordpress.com/2016/04/05/180/.

Shihab, Quraish. Wawasan al-Qur'an: Tafsir Mawdhu'i atas Berbagai Persoalan Umat. Bandung: Mizan, 1996.

Shihab, Quraish. Tafsir Al-Misbah: Pesan, Kesan dan Keserasian al-Qur'an. Jakarta: Lentera Hati, cet 6, Jilid 5 dan 9, 2006.

Sudrajat, Jilbab di Indonesia, Antara Pelarangan dan Perjuangan, 7 Mar 2018, https:// news.detik.com/berita/d-3903674/jilbab-di-indonesia-antara-pelarangandan-perjuangan.

Tibi, Bassam. Islamism and Islam. New Haven: Yale University Press, 2012.

UIN Sunan Kalijaga Yogyakartaa. Tata Tertib Mahasiswa. UIN Sunan Kalijaga Yogyakarta, 2018. 
Islamism and nationalism among niqabis women in Egypt and Indonesia (Siti Ruhaini Dzuhayatin)

Wijaya, Indra, "Bagaimana ISIS Masuk Indonesia?", tempo.co, 2014, https:// nasional.tempo.co/read/596975/bagaimana-isis-masuk-indonesia/ full\&view $=$ ok.

Wildan, Muhammad et. al. Menanam Benih di Ladang Tandus:Potret Sistem Produksi Guru Agama Islam di Indonesia. Yogyakarta: CISForm UIN Sunan Kalijaga Yogyakarta, 2019.

Interview List

Al Shafty, H. Hamdallah. interview, 1 Oct 2018.

Hamid, A. Muhammad. interview, 5 Nov 2018.

Jumirin, interview, 17 Nov 2018.

Maye, interview, 29 Oct 2018.

Muhsin, Mukhtar. interview, 4 Nov 2018.

Rozaki, Abdur. interview, Oktober 2018.

Sabain, interview, 17 Nov 2018.

Wardatun, Atun. interview, 17 Nov 2018.

Zia, interview, 22 Nov 2018. 
